\title{
To the problem of effective organization of pro- curement activities of construction companies
}

\author{
Vasiliy Makarov ${ }^{1, *}$, Inga Skvortsova ${ }^{2}$ and Roman Latyshev ${ }^{2}$ \\ ${ }^{1}$ Peter the Great St.Petersburg Polytechnic University, Polytechnicheskaya, 29, 195251, \\ St. Petersburg, Russia \\ ${ }^{2}$ LLC LSR. Construction - NW, 3rd Upper lane 5 litT, 194292, Saint-Petersburg, Russia
}

\begin{abstract}
The article considers organization of procurement activities of company, which works in a field of urban housing construction, as part of a single logistics supply chain of component parts. The article identified the factors which have influenced the level of centralization of purchases and the transfer of procurement activities to outsourcing. The conclusion is: the feasibility of a particular option for the organization of procurement is determined through feasibility analyses based on identified factors.
\end{abstract}

\section{Introduction}

The function of procurement in the construction industry is extremely important for the successful operation of the company. So the firm-builder working in the field of urban housing construction and which specializes in performing construction work, needs to receive directly the building structures and more than 600 types of components.

Nowadays, large construction companies in the Russian Federation are discussing the necessity to transfer all purchases to one centralized department, to stay in a decentralized procurement system or to find a compromise between these two systems. The departments dealing with purchases in construction companies are constantly reforming and reorganizing. Not all of them have a positive result. The unified concept of solving the problem has not been worked out yet. This problem has determined the subject of this research.

\section{The problem definition}

The method of procurement organization directly depends on the conditions the company operates in, on the scale of its activities and the geographical location of its production (branches, construction sites). The usual goal of the purchasing department is to receive goods and services taking into account the following three criteria: the highest quality, the lowest price and the shortest delivery time. It should be noted that these requirements are contradictory, therefore, purchasing decisions are always made in conditions of uncertainty and require a search for a compromise.

\footnotetext{
*Corresponding author: vmmak51@mail.ru
} 
Compliance with these criteria in the construction industry allows the general contractors to achieve the ultimate goal - to pass construction to the contracting authority in time. In case of housing construction with the co-investors - this procedure should be done with proper quality and according to the date in the contract. On the contrary, improper organization of purchases can lead to the cost of material's increase and changes in the building's timing of the construction. Because it leads to customer's dissatisfaction right up to legal actions on the part of equity holders.

\section{Logic of study}

Large construction companies often use a centralized procurement system. Due to the fact that organizations having several business units (branches, construction sites) in one region, conclude one general contract with the supplier.

The main advantage of the method of organizing purchases is reduction of cost of components and transportation due to an increase of total volume of purchases. Construction company can escape the tender departments or supply departments in separate business units, or minimize the staff of their employees by organizing a general department of centralized procurement. It should make a significant profit for construction companies.

When a company has a large territorial dispersion (it often takes place in the Russian Federation) it usually applies a decentralized procurement system. It is based on the fact that each business unit carries out purchases on its own. This type of organization of the procurement system does not allow to work with the maximum volumes of supplies, but it gives an opportunity to dialogue with regional wholesale intermediaries and producers. It allows to flexible more the local conditions: the characteristics of local producers' products, the conditions and methods of their delivery to construction sites, climatic features, etc. And due to the close territorial location, local suppliers have benefits by shortening the delivery time of the goods, as well as providing substitution in case of defects. The requirement for the decentralized system effectiveness is to make sure that the department personnel has a deep understanding of the region specifics and specifics of the building necessary product (service).

Also it should be noted that the centralized system is well adapted for typical purchases. If there is a necessity to deviate from typical purchases, the decentralized system has the advantage because it is more adapted to local conditions (Table 1). 
Table 1. Comparative analysis of the strengths and weaknesses of a centralized and decentralized systems.

\begin{tabular}{|c|c|}
\hline Centralized system & Decentralized system \\
\hline $\begin{array}{l}\text { Strengths: } \\
\text { - Procurement is carried out in large batches } \\
\text { - A unified database of reliable suppliers and } \\
\text { carriers. } \\
\text { - Reduction of cost of maintaining supply } \\
\text { services in the branches and offices. }\end{array}$ & $\begin{array}{l}\text { Strengths: } \\
\text { - More offers, because purchases are made in } \\
\text { small batches } \\
\text { - More qualified personnel responsive with } \\
\text { local specifics. } \\
\text { - Short delivery periods, and, if necessary - fast } \\
\text { return or exchange of goods. }\end{array}$ \\
\hline $\begin{array}{l}\text { Weaknesses: } \\
\text { - The system is convenient only for typical } \\
\text { products. } \\
\text { - The delivery period is longer. } \\
\text { - More complex process of return, or ex- } \\
\text { change of defective goods. }\end{array}$ & $\begin{array}{l}\text { Weaknesses: } \\
\text { - Increase costs of purchases. }\end{array}$ \\
\hline
\end{tabular}

Let's consider a common situation: the general contractor determines a necessity to deviate from the tipical solution due to certain external factors. As a result, an atypical purchase is required. There are two options for its implementation (Fig.1, 2).

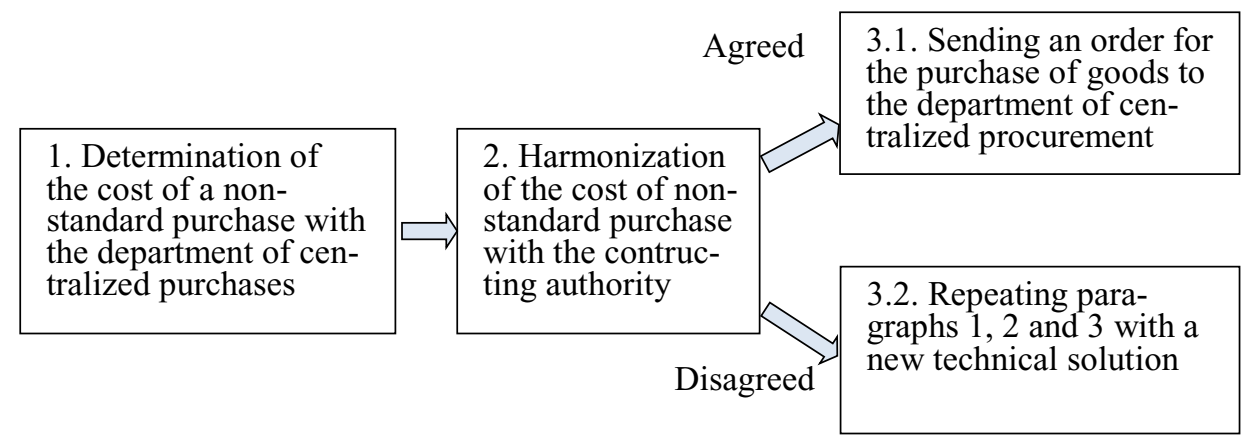

Fig. 1. Centralized system. The contracting authority, the general contractor and the central purchasing department are separate units or are locating in different business units.

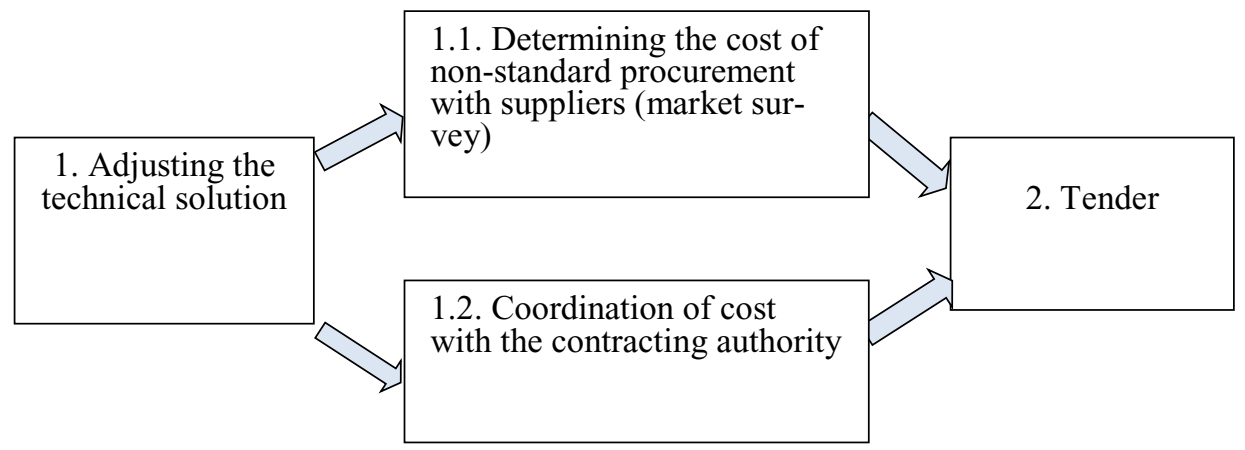

Fig. 2. Decentralized system. The Procurement Division is a division of the general contractor's business unit.

Using the example of this situation, it is clear that in a decentralized system the general contractor can make a market research and has a dialogue with the contracting authority. 
In the construction industry it's obvious that the standard solution deviation is not a particular case, but a routine process the following conclusion comes out. The standard goods and services purchasing have to be done centrally, and non-standard decisions should be made by the contractor itself - for example, within his own tender or estimate-contract department.

Another problem that has to be solved in the implementation of procurement materials for the construction of housing is the feasibility of involving intermediary firms. This problem occurs mainly in a decentralized procurement system. In this case, the intermediary (or intermediaries) assumes the centralized function of supplying construction in the region. The difference from the last one considered option is the necessity to pay for the mediator's services (Table 2.). On the other hand, the work of the centralized procurement department on the construction company is also paid and it is reflected to the cost of its products. The only difference is the profit: the intermediary firm can get it or the construction company itself. Of course it is preferable for it.

Table 2. Comparative analysis of the strengths and weaknesses of a centralized corporate system and the involvement of intermediary firms.

\begin{tabular}{|c|c|}
\hline $\begin{array}{c}\text { Centralized Corporate Purchasing } \\
\text { Service }\end{array}$ & $\begin{array}{l}\text { Centralization of procurement with the in- } \\
\text { volvement of intermediary firms }\end{array}$ \\
\hline $\begin{array}{l}\text { Strengths: } \\
\text { - Procurement is carried out in large batches } \\
\text { - A unified database of reliable suppliers } \\
\text { and carriers. } \\
\text { - Reduction of cost of maintaining supply } \\
\text { services in the branches and offices. }\end{array}$ & $\begin{array}{l}\text { Strengths: } \\
\text { - Procurement is carried out in large batches and } \\
\text { carriers. } \\
\text { - A unified database of reliable suppliers and } \\
\text { carriers. } \\
\text { - Reducing the cost of maintaining supply ser- } \\
\text { vices for small developers (branches of large } \\
\text { companies). } \\
\text { - Fast delivery. } \\
\text { - Simplified process of return or exchange of } \\
\text { defective goods because this function is assumed } \\
\text { by the intermediary }\end{array}$ \\
\hline $\begin{array}{l}\text { Weaknesses: } \\
\text { - The delivery period is longer } \\
\text { - More complex process of return, or ex- } \\
\text { change of defective goods. }\end{array}$ & $\begin{array}{l}\text { Weaknesses: } \\
\text { - The necessity to share profits with the interme- } \\
\text { diary. }\end{array}$ \\
\hline
\end{tabular}

The question is to feasible using an intermediary centralizing the procurement function, a corporate service which represents similar functions or solving problems with purchases independently by each branch of a construction company both to an assessment of centralization's effectiveness and to an assessment of outsourcing's effectiveness.

\section{Discussion}

This discussion shows one more aspect of the problem: the importance to the organization of transportation of purchased goods to the construction site. The cost of delivery is up to $30 \%$ of the cost of components. If we consider the issue even wider, it is clear that the procurement process should not be separated from the warehousing of components. Thus, it is clear a general situation: the construction site should be considered as the final link in the 
logistics chain, which includes many suppliers of components, transporting to the central warehouse, warehousing itself, transporting to the construction site, warehousing before installation (Figure 3). Moreover, the first three links of the chain can belong to both the company itself and the intermediary.

The peculiarity of housing construction, especially in a metropolis like SaintPetersburg, is in difficultness to organize warehousing of components directly on the construction site. We should not forget the possibility of stealing of small expensive goods (bathroom faucets), damaging of large and fragile goods (plastic pipes, sinks, toilets), damage to bath surfaces, etc. It happens because of lack of available warehouses near the sites with high building density. The solution is to fast delivery of components necessary for the component's installation according to principle of "Just in Time". Such organization of supplies is practically possible, but it is effective only if it has fast delivery: from a corporate central warehouse, or from a warehouse of intermediary. The latter option is encountered in housing construction more often due to a wide spread of construction sites in the region where the construction company operates. Thus, the delivery "Just in time" is very convenient for the construction company, but it has to be paid to the intermediary firm.

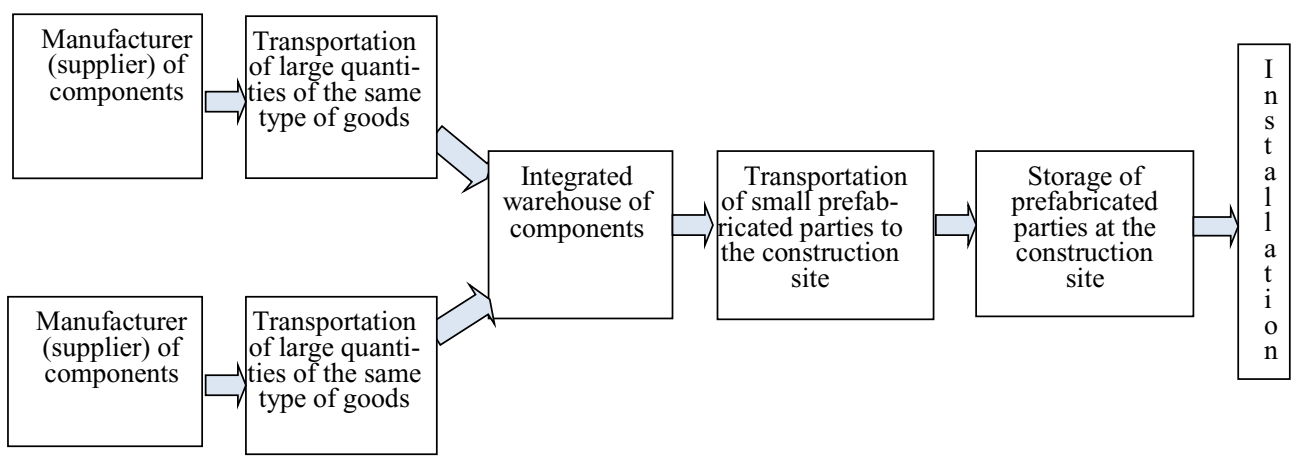

Fig. 3. Logistics chain of supplies of components to the construction site.

In all these situations the criterion for choosing the best option for organizing the logistics chain of supplies of components for widely used construction sites in the region is economic efficiency. At the same time, the main difficulties arise not in the choice of the methodology for calculating the indicators of economic efficiency, but in identifying and accounting for all the factors that has influence for the solution.

\section{Conclusion}

1. Procurement activities of a construction company should be viewed according to logistics' point of view. The movement of the material flow of component products should be subordinate to the laws of movement of logistical flows.

2. The level of centralization of procurement activities and the appropriateness of using intermediary firms are primarily determined by the dispersal of construction sites in the region of activity of the construction firm and the supply of services (prices) of intermediaries.

3. The best way to organize the logistics flow of components to the construction site is selected through feasibility analyses based on identified factors. 


\section{References}

1. I.V. Ilin, O.V. Kalinina, A.I. Levina, O.Yu Iliashenko, MATEC Web of Conferences, 05028 (2016)

2. R. Morledge, A. Smith, Building Procurement (Wiley-Blackwell, 2013)

3. A. Higham, C. Bridge, P. Farrell, Project Finance for Construction (Routledge, 2016)

4. F. Harris, R. McCaffer, F. Edum-Fotwe, Modern Construction Management, 576 (2013)

5. J. Mead, S. Gruneberg, Programme Procurement in Construction (Wiley-Blackwell, 2013)

6. R. Lambeck, J. Eschemuller, Urban Construction Project Management (McGraw-Hill Education, 2008)

7. P. Humbert, R.C. Mastice, Contract and Risk Management for Supply Chain Management Professionals, 312 (2014)

8. K. Masaaki, Y. M. Janet, Global procurement of service activities by service firms (EMR, 2004)

9. S. Kärnä, Analysing customer satisfaction and quality in construction - the case of public and private customers (NJSR, 2004)

10. J.E. Tookey, M. Murray, C. Hardcastle, D. Langford, EC\&AM, 20-30 (2001)

11. S. Gan, MP\&L, 113-115 (2011)

12. S. Rowlinson, P. McDermott, Procurement Systems: A Guide to Best Practice in Construction (1999)

13. D. Kashiwagi, R.E. Byfield, J of FM, 103-116 (2002)

14. R. Watermeyer, International Conference on Facilities Management, Procurement Systems and Public Private Partnerships, 13 (2012)

15. Construction procurement policies, strategies and procedures. Code of practice, BS 8534:2011 (2011) 